\title{
The application of gravity equation while accessing the environment of Pakistan-ASEAN technological trade flows
}

\author{
Muhammad Saqib Irshad ${ }^{*}$; Zhang Jian Wü ${ }^{2}$ Qi Xin ${ }^{3}$; Jahangir Khan ${ }^{4}$ \\ 1) Department of Economics, University of Jhang, Pakistan \\ ${ }^{1,2)}$ Department of Economics, Guangdong University of Foreign Studies, China \\ 3) College of International Trade, Tianjin University of Finance and Economics, China \\ 4) Department of Economics, Bacha Khan University, Pakistan
}

*To whom correspondence should be addressed: Email: drmsaqib@ hotmail.com

\begin{tabular}{|l|l|l|l|l|}
\hline DOI: & Received: & Revised: & Accepted: & Published: \\
10.22437/ppd.v9i1.12242 & 04.03 .2021 & 26.04 .2021 & 28.04 .2021 & 30.04 .2021 \\
\hline
\end{tabular}

\begin{abstract}
International trade, an important economic activity, has affected the human environment in varying degrees since its beginning. This research will carry out calculations and analyses on Pakistan-ASEAN bilateral and technological trade flows at a disaggregated level over 1995-2018. The current study found that medium-tech, high-tech, and lowtech trade flows, enhance economic growth in Pakistan and ASEAN, negatively impacting geographical distance by all technological trade flows. Similarly, the proportional element endowment confirms the Hecksher-Ohlin hypothesis. Yet, the perspective argues that countries with high production levels can exchange faster than their countries with lower output levels. Due to the variety in consumers' taste, increased similarity yields increased technological trade volumes, highest values received by medium-tech trade flow, and total bilateral trade flow. Depreciation in exchange rates showing a positive sign for total bilateral trade, low-tech trade, and hightech trade, whereas unenthusiastic in the case of medium-tech trade flow between Pakistan-ASEAN nations. Free trade agreement and WTO membership will also foster trade activities in conscientious and economic association in ecumenical. Pakistan trade patterns are different from ASEAN trade patterns, which increased the opportunity to enhance business activities.
\end{abstract}

Keywords: ASEAN, Bilateral trade, Gravity model, Pakistan, Panel data

JEL Classification: F14, F15, F18

\section{INTRODUCTION}

Liberalization of the economy has steadily encouraged trade development in recent decades. In the Asian area, the role of trade liberalization is a matter of great concern and priority. In South Asia, economic integration has been a slow process in contrast to other Asian countries. Moreover, there is a growing tendency in globalization (new realities arising from the worldwide perspective), leading Pakistan to reassert its place in East Asia and Oceania. This transition has also been significantly mirrored in Pakistan's policy in recent years, emphasizing improving diplomatic and sophisticated interactions, growing trade, magnetizing investment, and enhancing 
collaboration in several areas underneath the broad structure of vision East Asia (Irshad et al., 2016).

These days, trade is more than a "trade." It is clear that trade has been the dominant instrument of strategic policymaking in recent decades because of globalization. Irshad \& Xin (2015) think Pakistan's position is its greatest strength, but it has yet to use it fully. Interaction between cultures and nations encouraged crosscultural exchange and compelled the transformation of knowledge, skill, and skills. For now, Pakistan is talking with the ASEAN members about developing relations with them to increase cultural activities.

The living standards of 800 million Pakistanis are rising due to the economic revolution. The economic levels and the purchasing power of the people are similar compared to others developed economies. So, Pakistan has great potential in ASEAN countries to increase its trade and cultural ties, and for ASEAN nations, Pakistan is a great hub for long-term investment plans in nearly all sectors.

Pakistan has long term trade associations with ASEAN countries for the last three decades; thereupon, Pakistan had signed Free Trade Agreements (FTA) with independent ASEAN members. Pakistan-Malaysia FTA was signed and in operation in 2008, followed by Pakistan-Indonesia FTA signed and in force in 2013, whereas proposed and negotiations launched with individual members such as the Philippines in 2004, Singapore in 2005, with Thailand and Viet Nam in 2015. Pakistan also has endeavored to involved Pakistan-ASEAN FTA, which has been launched negotiations since 2009. Pakistan envisages expanding cooperation in various sectors along with institutional connection with ASEAN members independently and communally.

Figure 1 demonstrates that Pakistan's trade enrolment with its percentage share with ASEAN. The total export to ASEAN countries accounts for US\$ 0.3 billion in 1995, which is increased to US\$ 1.3 billion in 2018. Similarly, total imports from ASEAN collectively accounted for US\$ 1.5 billion in 1995, which is augmented to US\$ 6.4 billion in 2018 .

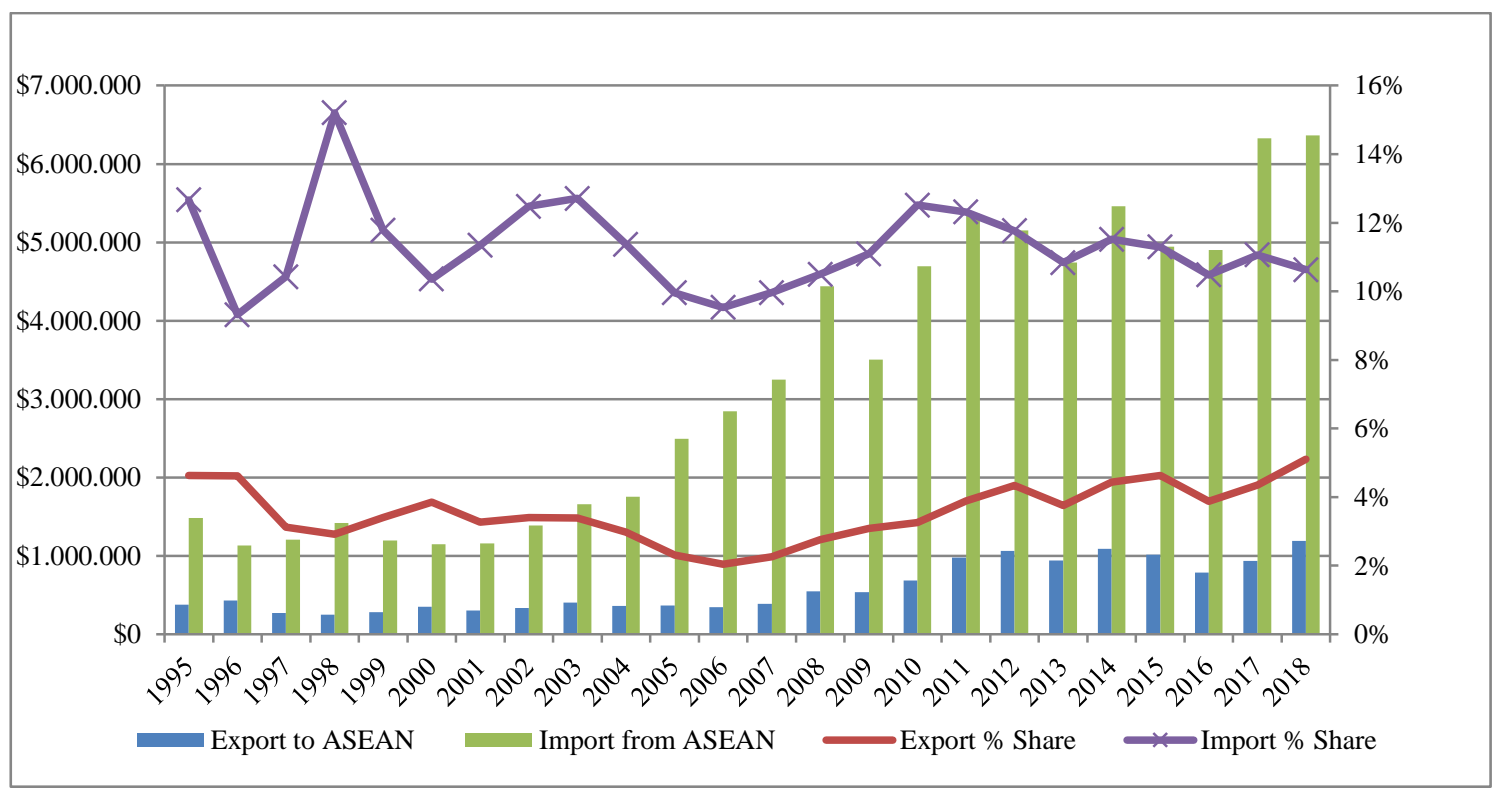

Source: Author's compilation based on UN Comtrade database 2020.

Figure 1. The Pakistan-ASEAN trade capabilities in US\$1000

Pakistan's leading export partner is Indonesia, with a 25 percent share of total ASEAN, followed by Vietnam's 24 percent share accounted for US\$ 298 million and 
US\$ 282 million respectively in the year 2018. In the case of Import leading partner of Pakistan in ASEAN members, Indonesia stands first with 39 percent share in total import from ASEAN, followed by Thailand with a share of 23 percent, which is accounted for US\$ 2493 million and US\$ 1430 million in the 2018 year (Table 1).

Table 1. Two decades comparative trade analysis of Pakistan-ASEAN (US\$1000)

\begin{tabular}{l|rrrr|rrrr}
\hline \multirow{3}{*}{ Country } & \multicolumn{4}{|c|}{ Exports } & \multicolumn{4}{c}{ Imports } \\
\cline { 2 - 9 } & 1995 & $\begin{array}{c}\text { Share } \\
(\%)\end{array}$ & 2018 & $\begin{array}{r}\text { Share } \\
(\%)\end{array}$ & 1995 & $\begin{array}{r}\text { Share } \\
(\%)\end{array}$ & 2018 & $\begin{array}{r}\text { Share } \\
(\%)\end{array}$ \\
\hline Brunei & 2920 & 0.8 & 797 & 0.1 & 180 & 0.0 & 37 & 0.0 \\
Cameroon & 1499 & 0.4 & 14879 & 1.2 & 16 & 0.0 & 2658 & 0.0 \\
Indonesia & 108388 & 28.8 & 298422 & 25.0 & 119111 & 8.0 & 2492713 & 39.2 \\
Lao PDR & 207 & 0.1 & 1210 & 0.1 & 56 & 0.0 & 1914 & 0.0 \\
Malaysia & 47037 & 12.5 & 156197 & 13.1 & 988247 & 66.7 & 1156772 & 18.2 \\
Myanmar & 2802 & 0.7 & 19036 & 1.6 & 30794 & 2.1 & 1937 & 0.0 \\
Philippines & 30838 & 8.2 & 110560 & 9.3 & 4045 & 0.3 & 64307 & 1.0 \\
Singapore & 89025 & 23.7 & 95394 & 8.0 & 225004 & 15.2 & 864483 & 13.6 \\
Thailand & 61690 & 16.4 & 213619 & 17.9 & 110310 & 7.4 & 1430022 & 22.5 \\
Vietnam & 31582 & 8.4 & 282034 & 23.7 & 4755 & 0.3 & 349754 & 5.5 \\
\hline ASEAN & 375988 & 100 & 1192147 & 100 & 1482519 & 100 & 6364597 & 100 \\
\hline
\end{tabular}

Source: Author's compilation based on UN Comtrade database 2020.

This study's major purpose is to get a clear eye on Pakistan-ASEAN trade and its impact on economies of both regions and income levels; infrastructure and development of Pakistan, and check if the FTA signed by both Pakistan and ASEAN will it accelerate trade between them. An analysis will employ an econometric model known as the gravity model and use a panel framework between 1995 and 2018. The variables are based on the literature of gravity model, in which variables including economic, political, and geographical influences.

This analysis aims to examine Pakistan's trade role with ASEAN and figure out the potential for trade cooperation with the neighboring nation. This research uses the Poisson Pseudo Maximum Likelihood (PPML) method in mathematical model estimation by Silva \& Tenreyro $(2006,2011)$. This theory works best in the existence of heteroskedasticity along with zeroes trade observation. Based on current research findings, new conclusions for Pakistan's policymakers and industry and the coalition of ASEAN can be derived.

\section{LITERATURE REVIEW}

As globalization begins to transcend national borders, economies field gradually comes into contact with one another. Tinbergen (1962) had analyzed the interaction between GDP along with trade flows using a gravity model. The interest in Pakistan's economic influence on ASEAN is not widely explored, which is the research's key objective to study Pakistan's ASEAN members' bilateral exchange. Later Poyhonen (1963) established that trade between countries hinges on their distance and income.

Work included studies containing our views and ASEAN FTA study with other countries. For e.g., Kien (2009) carried out ASEAN free trade research by analyzing the export flows determinants of ASEAN countries using panel data estimates using a period 1988-2002 gravity model based on a two-way error component. The impact of ASEAN Free Trade Agreements (FTAs) with other countries and at the sectoral level has been studied (Kreinin \& Plummer 1992; Plummer 1997; Clarete et al. 2003). 
Besides, Naya \& Plummer (2006) have also explored the prospect of referring the ASEAN regional grouping to a 'normal economic bloc.'

Further contributions discuss many topics, for example, the evaluation of how Asia's (including ASEAN) most productive way to build Batra's (2006) economic inclusion and whether regional trade blocs are precursors to multilateral trade liberalization Baharumshah et al. (2007).

Thorbecke's (2015) analysis estimated that Chinese exports to the United States are an outlier in a gravity model. The evaluation results show that since 2005 such exports are more than expected per year. Rasoulinezhad (2016) explores the degree, by gravity model, to influence Iran's foreign trade with Russia in 1994-2013 and the numerous sanctions (financial and non-financing) and oil prices. The negative ties with the trade between Iran and Russia between financial, non-financial, and petroleum price shocks were concluded.

In 2001-16, Irshad \& Xin (2017) used different evaluation methods to analyze South Korean foreign trade. Their findings have shown that South Korea's trading patterns of imports and exports rely on GDP, trade ingenuousness, regional trade, along with exchange agreements, thus having an adverse impact on transport costs and the landlocked geographical countries. Irshad et al. (2018) also analyzed China's trade with the OPEC nations in the 1990-2016 periods. The findings confirmed the positive influence of Chinese bilateral trade with OPEC countries on GDP, GDP per capita, China's free trade and OPEC WTO nations, and the adverse effects on trade costs and support for the Linder hypothesis. Irshad and Anwar (2019) have endeavored to explore and become aware of dormant markets with Pakistan's bilateral exchange over the past 25 years with 198 trading cohorts (1992-2016). Empirical findings show that the size of the economy, mutual exchange rates, differential wages, common faith, frontier, and trade agreements optimistically impact bilateral trade volume.

In contrast, bilateral and landlocked countries show hostile relations between Pakistan and the rest of the world. Iqbal \& Nosheen's (2020) study applies widespread gravity models to evaluate Pakistan's bilateral commodity trade flows employing both the panel and cross-section data estimations. Their research shows that trade costs are considerable and negatively correlated with commodity trade flows between Pakistan and its trading partners. In contrast, other empirical results by Hoang et al. (2020) measures trading links between Taiwan and ASEAN countries by using a PPML (pseudo-maximum similarity) gravity model for the periods 200-2017. They find that ASEAN's economic size and per capita income have considerably more significant impacts on gross trade and development than those of Taiwan.

\section{METHODS}

The gravity model has been known as the "workhorse" for evaluating foreign trade. Other "flagship" trade theories are critical for deciding the dynamics of import and export performances. It is the gravity that will decide the real trade flows, Irshad et al. (2018).

\section{Model creation}

Many researchers have been extremely active in improving the literature of the original gravity model and applying it through observational studies. One of the most productive variants was an arrangement suggested by Anderson \& Wincoop (2003). The standard gravity equation was claimed as being distorted because the implications of multilateral resistance terms were not accounted for. The equation is seen as follows. 
$\operatorname{Ln} B T_{i j}=\alpha_{0}+\alpha_{1} \operatorname{Ln}\left(Y_{i} * Y_{j}\right)+\alpha_{2} \operatorname{Ln}\left(T C_{i j}\right)+\alpha_{3} \operatorname{Ln}\left(R_{i j}\right)+\alpha_{4} \operatorname{Ln}\left(\varphi_{i j}\right)+\varepsilon_{i j}$

Where $B T_{i j}$ is the bilateral technological trade flows among Pakistan and ASEAN countries, $\left(Y_{i} * Y_{j}\right)$ represents the gross domestic product of Pakistan and partner country, $\left(T C_{i j}\right)$ the geographical distance between Pakistan and partner country took as a proxy for trade cost; $\left(R_{i j}\right)$ is trading multilateral resistances, $\left(\varphi_{i j}\right)$ is dummy variable, and $\left(\varepsilon_{i j}\right)$ is a random error term.

$$
B T_{i j}=H T T_{i j}+M T T_{i j}+L T T_{i j}
$$

Whereas $H T T_{i j}$ high technological trade, $M T T_{i j}$ medium technological trade and $L_{T T} T_{i j}$ low technological trade. The research will be undertaken to assess the scale of overall bilateral and disaggregated trade flows such as high-tech, medium-tech, and low-tech between Pakistan and Southeast Asian countries by employing an augmented gravity model equation. The equations should be as follows:

$$
\begin{aligned}
& \boldsymbol{B T}_{i j t} / \mathrm{HTT}_{i j t} / \mathrm{MTT}_{i j t} / \mathrm{LTT}_{i j t}=\exp \left\{\beta_{0}+\beta_{1} \operatorname{Ln}\left(Y_{i t} * Y_{j t}\right)+\beta_{2} \operatorname{Ln}\left(T C_{i j t}\right)+\right. \\
& \beta_{3} \operatorname{Ln}\left(R E F_{i j t}\right)+\beta_{4} \operatorname{Ln}\left(\operatorname{Simi}_{i j t}\right)+ \\
& \beta_{5} \operatorname{Ln}\left(\text { Exrate }_{i j t}\right)+\beta_{6} \operatorname{Ln}\left(T o_{i t} * T o_{j t}\right)+ \\
& \beta_{7}\left(F T A_{j t}\right)+\beta_{8}\left(W T O_{j t}\right)+\mu_{j}+\pi_{t}+ \\
& \left.\varepsilon_{i j t}\right\}
\end{aligned}
$$

Where $B T_{i j t}$ stands for bilateral technological trade flows, $H T T_{i j t}$ high-tech trade, $M T T_{i j t}$ medium-tech trade and $L T T_{i j t}$ low-tech trade among Pakistan, and ASEAN countries, respectively. $\left(Y_{i t} * Y_{j t}\right)$ represents the gross domestic product of Pakistan and ASEAN countries.

The distance calculation in this analysis used by Head and Mayer (2002) uses key agglomerations and populations' data of cities, towns, and places that provide geographical coordinates and population statistics for all countries. $\left(T C_{i j t}\right)^{1}$ Weighted distance as a substitute for trade expenditure between country $\mathrm{i}$ and $\mathrm{j}$, a sign is hypothetical to be negative. $\left(R E F_{i j t}\right)$ a proxy for factor endowment and $\left(S i m i_{i j t}\right)$ represents the similarity index between trading partners. $\left(R E F_{i j t}\right)$ acquires a minimum of zero if both partners demonstrate equal GDP or production.

The assortment of SIM is specified by, $0 \leq\left(\right.$ Simi $\left._{i j t}\right) \leq 0.5$; where 0.5 means 'equal' and zero implies 'absolute divergence' in country size ${ }^{2}$. Presently two variables can be defined in this manner:

$$
\begin{aligned}
& \left(R E F_{i j t}\right)=\left[\ln \left(P C G D P_{i t}\right)-\ln \left(P C G D P_{j t}\right)\right] \ldots \ldots \ldots \ldots . . \\
& \left(\text { Simi }_{i j t}\right)=1-\left(\frac{\ln \left(g d p_{i}\right)}{\ln \left(g d p_{i}+g d p_{j}\right)}\right)^{2}-\left(\frac{\ln \left(g d p_{j}\right)}{\ln \left(g d p_{i}+g d p_{j}\right)}\right)^{2}
\end{aligned}
$$

\footnotetext{
${ }^{1}$ The general formula developed by Head \& Mayer (2002) and used for calculating distances between country $i$ and $j$ are $\left(T C_{i j}\right)=\left(\sum_{k \in i}\left(\frac{p o p_{k}}{\text { pop }_{i}}\right) \sum_{l \in j}\left(\frac{\text { pop }_{l}}{\text { oop }_{j}}\right) d_{k l}^{\theta}\right)^{\frac{1}{\theta}}$,Where opp $_{k}$ designates the population of agglomeration $k$ belonging to country $i$. The parameter $\Theta$ measures the sensitivity of trade flows to bilateral distance $d_{k l}$.

${ }^{2}$ Breuss \& Egger (1999), Egger (2000, 2002), and Serlenga \& Shin (2007) define SIM in the following way:

$\left(\operatorname{Simi}_{i j t}\right)=\ln \left[1-\left(\frac{g d p_{i}}{g d p_{i}+g d p_{j}}\right)^{2}-\left(\frac{g d p_{j}}{g d p_{i}+g d p_{j}}\right)^{2}\right]$, In this definition, the index does not range between zero and 0.5 because the value under the bracket is a fraction, and the natural log of a fraction is something negative so we followed Kabir \& Salim (2010).
} 
According to Egger (2000), relative factor endowment (REF) is defined as the absolute value of the factor endowment of goods divided by the factor endowment of labor. However, it is generalized by using the absolute value of the dissimilarity between per-capita GDP and the normal logarithm (Egger, 2002).

Baltagi et al. (2003) and Serlenga \& Shin (2007) both follow Egger's (2002) description of the REF, suggesting that the greater the dissimilarity in each country's per capita income, the subordinate the share of bilateral trade. A greater per capita income consequences in greater performance of goods and services and a lower trade deficit (Bergstrand, 1990). Capital-intensively enterprises prefer to manufacture more differentiated goods, and intra-industry specialization is more common in countries with higher average capital-labor ratios. Thus a bigger share of intra-industry trade is expected from capitalists. Bergstrand (1990) has shown that the gravity equations can describe the effect on the level of trade in intra-industry between two countries of the disparities in national and per capita income and capital-labor ratios.

The currency exchange rate plays a major role in a country's trade efficiency. As a consequence of the demand, when the supply is high, the price goes up, and hence the currency appreciates in value. When the country exports more than imports, the exchange rate will probably be higher when the exchange rate is fair when prices are released. When capital loses its worth, it can be said to depreciate. To observe this phenomenon, the study includes $\left(\right.$ Exrate $_{i j t}$ ) which represents bilateral exchange rates.

Trade liberalization is the elimination or diminution of restrictions or other obstructions on the gratis exchange of goods between nations. Trade to GDP ratios proxy for openness is employed in this study represents $\left(T o_{i t} * T o_{j t}\right)$. The current study has included two dummy variables to grasp the impact of the trade agreement and membership to a world trade organization (WTO) whereas, $\left(F T A_{j t}\right)$ takes a value of 1 if both countries have the trade agreement in a given year otherwise zero, and similarly $\left(W T O_{j t}\right)$ would take a value of 1 if the partner country joined WTO in a given year. With the purpose of discovering the role of the membership of WTO on the trade of Pakistan with ASEAN nations, this variable is included in the above equation.

The equation (2) of time and region-specific consequences has also been calculated to help monitor various other macroeconomic variables, such as the world economic boom or recessions and the country effects of Silva and Tenreyro (2011) as to how the endogenous issues should be overcome. There is a good explanation of why countries-specific fixed effects $\left(\mu_{j}, \pi_{t}\right)$ should be acceptable if trade flows (geographical, political, or chronological determinants) are involved in export or import impacts or 'environmental determinants. These considerations are deterministically related to the diligent distinctiveness of a country and cannot be considered arbitrary.

Successive researchers reflected on several possible shortcomings of the gravity model specification, including potential endogeneity dilemma (Trefler, 1993; Lee \& Swagel, 1997), zero exchange dilemma (Hallak, 2006; Helpman et al., 2008), and the issue of heteroscedasticity. Explanation of the endogenous problem was suggested by the inclusion of differences in types of fixed effects during the estimation of the gravity model (Baier \& Bergstrand, 2007; Magee, 2003 ). Silva \& Tenreyro (2006) predicted the gravity model estimator of Poisson-Pseudo Maximum Likelihood (PPML), which is incredible for the heteroskedastic degree of trading performance. Subsequently, Silva \& Tenreyro (2011) found that there is also continuity in the existence of zero commercial observation in the PPML estimator. 


\section{Data sources}

The dataset is an unprejudiced panel containing yearly bilateral trade flows, which are disaggregated by dissimilar technological trade flows. For instance, low-tech, medium-tech, and high-tech trade flows between Pakistan and ten ASEAN nations. Data is collected for the time ranging from 1995-2018, and total observations are $(24 \times 10=240)$. The variables used in our gravity equation (Table 2$)$ comprising the predicted signs and data sources are explained.

Table 2. Description of variables

\begin{tabular}{|c|c|c|c|c|}
\hline Variables & Unit & Type & $\begin{array}{l}\text { Expected } \\
\text { Sign }\end{array}$ & Data Source \\
\hline$B T_{i j t}$ & $\begin{array}{l}\text { US\$ } \\
1000\end{array}$ & Time-Variant & - & $\begin{array}{l}\text { UN Comtrade Databasel Pakistan } \\
\text { Bureau of Statistics }\end{array}$ \\
\hline$H T T_{i j}$ & $\begin{array}{l}\text { US\$ } \\
1000\end{array}$ & Time-Variant & - & $\begin{array}{l}\text { UN Comtrade Database/ Pakistan } \\
\text { Bureau of Statistics }\end{array}$ \\
\hline$M_{T T} T_{i j}$ & $\begin{array}{l}\text { US\$ } \\
1000\end{array}$ & Time-Variant & - & $\begin{array}{l}\text { UN Comtrade Database/ Pakistan } \\
\text { Bureau of Statistics }\end{array}$ \\
\hline$L T T_{i j}$ & $\begin{array}{l}\text { US\$ } \\
1000\end{array}$ & Time-Variant & - & $\begin{array}{l}\text { UN Comtrade Databasel Pakistan } \\
\text { Bureau of Statistics }\end{array}$ \\
\hline$\left(\boldsymbol{Y}_{i t} * \boldsymbol{Y}_{j t}\right)$ & $\begin{array}{l}\text { US\$ } \\
1000\end{array}$ & Time-Variant & Positive & WDI, World Bank \\
\hline$\left(R E F_{i j t}\right)$ & $\begin{array}{l}\text { US\$ } \\
1000\end{array}$ & Time-Variant & Ambiguous & WDI, World Bank \\
\hline$\left(\operatorname{Simi}_{i j t}\right)$ & Ratio & Time-Variant & Positive & WDI, World Bank \\
\hline$\left(T C_{i j t}\right)$ & Weighted & Time-Invariant & Negative & CEPII database \\
\hline$\left(\right.$ Exrate $\left._{i j t}\right)$ & Rupee & Time-Variant & Positive & WDI, World Bank \\
\hline$T O_{i t} \cdot T O_{j t}$ & $\%$ & Time-Variant & Positive & WDI, World Bank \\
\hline$F T A_{i j t}$ & $(0 / 1)$ & Time-Invariant & Positive & $\begin{array}{l}\text { Asia Regional Integration Center } \\
\text { https://aric.adb.org/fta-country }\end{array}$ \\
\hline$W T O_{i j t}$ & $(0 / 1)$ & Time-Invariant & Positive & World Trade Organization \\
\hline
\end{tabular}

Source: Authors' Compilation

\section{RESULTS AND DISCUSSIONS}

\section{Pakistan-ASEAN technological trade analysis}

The changing global climate and East Asia's rising centrality are moving Pakistan into East Asia. As a result of the transition, an emphasis has been put on the trade and investment and collaboration in many sectors.

Pakistan will improve its foreign trade with ASEAN by changing its foreign trade policy and promoting private-sector investments in the region. In signing free trade deals with South Asia regional bloc ASEAN to facilitate regional trade, Pakistan is in the process of signing free trade. In dealing with this issue, the first Southeast Asian economic ministers meeting took place in Bangkok in 2009. While there is a tremendous opportunity for Pakistan to trade with ASEAN members, there are also long-term growth and development prospects due to joint ventures. The ASEAN nations are emerging markets that wish to join regional partners for economic growth.

Figure 2 has shown a huge shift in technological trade between Pakistan and ASEAN nations. Pakistan mainly exports low-tech goods to ASEAN countries that counted USD 174 million in 1995, grown by USD 221 million in 2018. Similarly, medium-tech goods took second place in Pakistan's total exports to ASEAN, which 
accounted for USD 69 million in 2018 compared to USD 17 million in 1995. Pakistan is not specialized in high-tech goods, which can be seen.

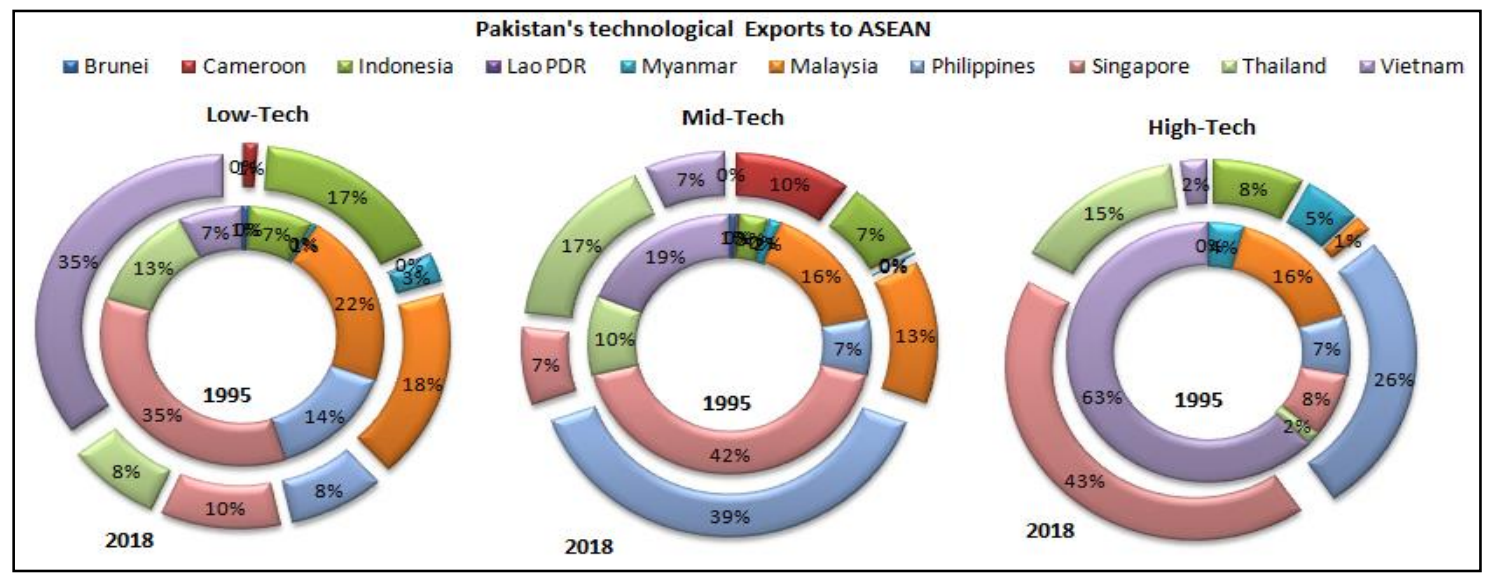

Source: Author's compilation based on WITS database.

Figure 2. Comparative analysis of Pakistan's technological exports to ASEAN

In each country's economy, exports play a critical role. Pakistan is supposed to uphold a robust balance between international trade and foreign reserves while ensuring economic growth in the region. The level of export growth in Pakistan should be persistent and intense. Exports affect the entire industrial world. To participate internationally, the industry is obliged to have standard superiority products, competitive prices, decent worth, and packaging in compliance with international labeling and packing laws, export functions as a driving force for a fast-expanding economy, and articulate a significant competitor on the global market.

Pakistan's largest imports from ASEAN countries are Medium-tech goods, USD 153 million in 1995, whereas a dramatic boost in later years accounted for USD 1945 million in 2018. In contrast, Thailand shares 51 percent of total imports from ASEAN, followed by Singapore 20 percent, and Indonesia 18 percent see (Figure 3).

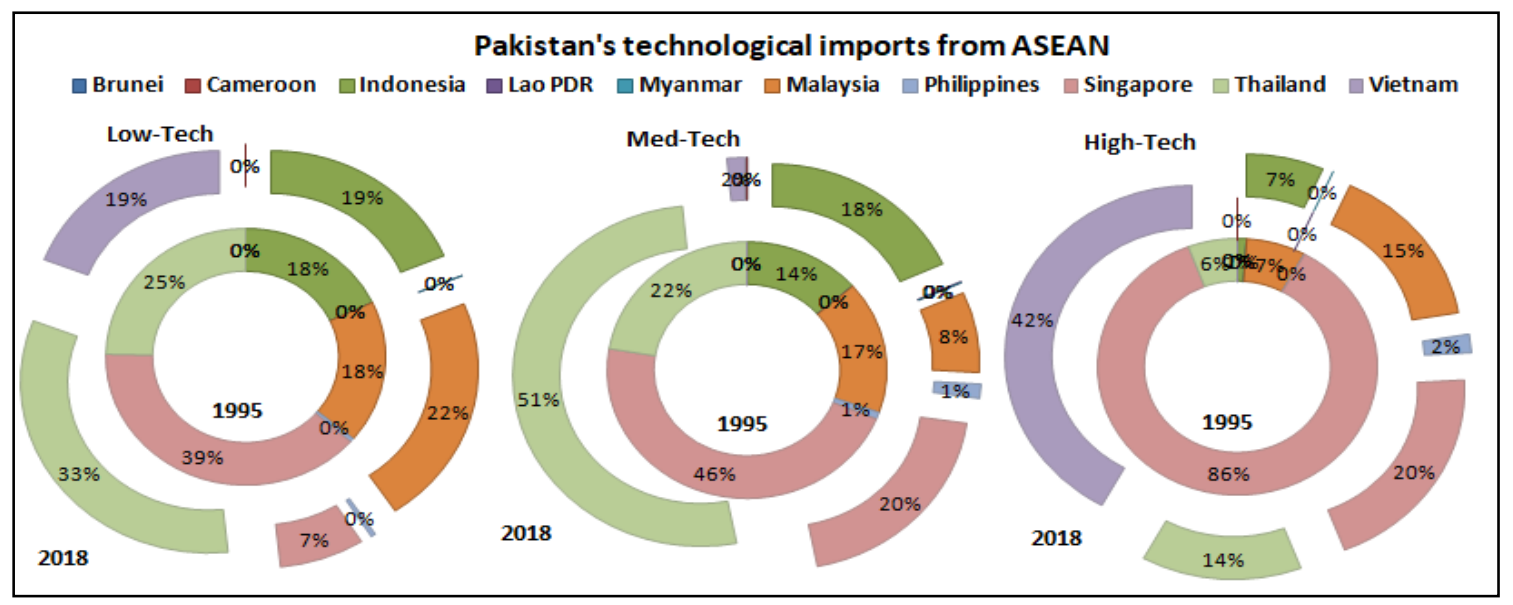

Source: Author's compilation based on WITS database.

Figure 3. Comparative analysis of Pakistan's imports from ASEAN countries.

ASEAN investors sponsor investors from ASEAN countries to invest in Pakistan's agriculture, livestock, roads, electricity, cars, and many other sectors. The scope for bilateral or multilateral trade between Pakistan and ASEAN nations to grow is enormous (Musleh et al., 2009). Bilateral trade can further improve the competitiveness, living standards, and long-term development of economies by encouraging a more well- 
organized distribution of capital and initiating the engine of development in Pakistan and ASEAN nations.

\section{Gravity estimations}

The cross-sectional dependency of panel data has been widely regarded over the years and is an emerging area of study in panel time-series analysis. There is a possible risk for the emergence of the world, traditional shocks like the oil crisis in the 1970s and the global financial crisis from 2008 onwards. This condition may result from spillover effects between countries or regions (Eberhardt \& Teal, 2011; Moscone \& Tosetti, 2009). The hypothesis test can be used to assess whether survey data are crosssectionally dependent or independent. Without these conclusions (Breusch \& Pagan, 1980; Pesaran, 2004 ), gravity model effects will not be correct. According to the time and cross-sections equation of gravitation, Pesaran (2004), the correlation coefficient $\hat{C}_{i j}$ the following study calculates pairs:

$$
C D=\sqrt{\frac{2}{N(N-1)}} \sum_{i=1}^{N} \sum_{j=i+1}^{N} \sqrt{T_{i j} \hat{\mathrm{C}}_{i j}}
$$

We have calculated the $\mathrm{CD}$ test only for time-variant variables in our gravity equation because of $\mathrm{CD}$ test unable to define in the case of time-invariant variables, as Irshad et al. (2018) mentioned. There are zero values in our dependent variable, and we have dropped dummies because it is not definable in the CD test; however, we calculate it with the whole sample. Based on the result of Pesran's (2004) CD test, shown in Table 3, the null hypothesis (no CD in residuals) can be strongly rejected at the 5 percent level. It implies that all the panel time series have strong evidence for crosssectional dependence.

Table 3. Results of Pesran's (2004) CD test.

\begin{tabular}{lllll}
\hline \multirow{2}{*}{ Variables } & \multicolumn{4}{c}{ Pesaran's CD test } \\
\cline { 2 - 5 } & Bilateral Trade & High-Tech & Med-Tech & Low-Tech \\
\hline$B T_{i j t}$ & $11^{* * *}$ & - & - & - \\
$H T T_{i j}$ & - & $7.2 * * *$ & - & - \\
$M T T_{i j}$ & - & - & $10.6 * * *$ & - \\
$L T T_{i j}$ & - & - & - & $5.07 * * *$ \\
$\left(Y_{i t} * Y_{j t}\right)$ & $32.57 * * *$ & $32.57 * * *$ & $32.57 * * *$ & $32.57 * * *$ \\
$\left(R E F_{i j t}\right)$ & $3.68^{* * *}$ & $3.68^{* * *}$ & $3.68^{* * *}$ & $3.68^{* * *}$ \\
$\left(\right.$ Simi $\left._{i j t}\right)$ & $8.36^{* * *}$ & $8.36^{* * *}$ & $8.36^{* * *}$ & $8.36^{* * *}$ \\
$\left(\right.$ Exrate $\left._{i j t}\right)$ & $11.71^{* * *}$ & $11.71^{* * *}$ & $11.71^{* * *}$ & $11.71^{* * *}$ \\
TO $_{i t} . \mathrm{TO}_{j t}$ & $8.93^{* * *}$ & $8.93^{* * *}$ & $8.93^{* * *}$ & $8.93^{* * *}$ \\
\hline
\end{tabular}

*** represents zero percent probabilities value.

Source: Authors' compilation from STATA 14.0.

After confirming the cross-sectional dependency in our variables, the regression outcomes for gravity equation (3) are presented in Table 4. All the technological trade flow models are demonstrating anticipated signs and greatly significant fallout.

To answer the endogenous problem, equation (3) is calculated to be time-fixed effects; other macroeconomic aspects can be conveniently managed, such as a worldwide economic boom or slump suggested by Yang \& Martinez (2014). Higher GDP of an economy that imports prices would have a favorable and statistically meaningful impact on trade because it indicates the ability to have a higher demand for economies that consume commodities. In exchange, a higher GDP of the exporter shows greater output capacity, thereby leading to elevated exports. Study outcome originates; this is factual for Pakistan's technological trade flows to ASEAN countries 
in all the estimated models that have noticed highest in case of medium-tech trade flow increase by 1 percent will increase 2 percent in GDP of Pakistan and trading partners.

In the case of a geographical distance as a transportation cost proxy, its coefficient's negative sign reflects the geographical distance negatively affecting all models on Pakistan's technological trade flows into ASEAN countries. Estimation shows that the highest trade cost occurred while med-tech trade flows between Pakistan and ASEAN nations by 1 percent increase in distance will decrease 20 percent med-tech trade flows between Pakistan and ASEAN.

Table 4. Gravity results of all technological trade models PPML estimation technique.

\begin{tabular}{|c|c|c|c|c|}
\hline Explanatory Variables & $\begin{array}{l}\text { Bilateral } \\
\text { Trade }\end{array}$ & High-Tech & Med-Tech & Low-Tech \\
\hline Coefficient & $\begin{array}{l}-8.36 \\
(3.3)^{* *}\end{array}$ & $\begin{array}{l}-18.6 \\
(3.02)^{* * *}\end{array}$ & $\begin{array}{l}2.2 \\
(3.23)\end{array}$ & $\begin{array}{l}-5.33 \\
(2.02) * * *\end{array}$ \\
\hline$\left(\boldsymbol{Y}_{i t} * \boldsymbol{Y}_{\boldsymbol{j} t}\right)$ & $\begin{array}{l}0.44 \\
(0.5)^{* * * *}\end{array}$ & $\begin{array}{l}0.4 \\
(0.6) * * *\end{array}$ & $\begin{array}{l}0.66 \\
(0.05)^{* *}\end{array}$ & $\begin{array}{l}0.32 \\
(0.03) * * *\end{array}$ \\
\hline$\left(T C_{i j t}\right)$ & $\begin{array}{l}-0.7 \\
(0.24) * * *\end{array}$ & $\begin{array}{l}-1.24 \\
(0.27)^{* * *}\end{array}$ & $\begin{array}{l}-3.0 \\
(0.28)^{* * *}\end{array}$ & $\begin{array}{l}-1.13 \\
(0.15)^{* * *}\end{array}$ \\
\hline$\left(\boldsymbol{R E} \boldsymbol{F}_{\boldsymbol{i j t}}\right)$ & $\begin{array}{l}0.3 \\
(0.14)^{* *}\end{array}$ & $\begin{array}{l}0.53 \\
(0.15) * * *\end{array}$ & $\begin{array}{l}0.37 \\
(0.1)^{* * *}\end{array}$ & $\begin{array}{l}0.1 \\
(0.03)^{* *}\end{array}$ \\
\hline$\left(\operatorname{Simi}_{i j t}\right)$ & $\begin{array}{l}7.02 \\
(1.1)^{* * *}\end{array}$ & $\begin{array}{l}2.6 \\
(0.9)^{* * *}\end{array}$ & $\begin{array}{l}7.82 \\
(1.1)^{* * *}\end{array}$ & $\begin{array}{l}4.9 \\
(0.45)^{* * *}\end{array}$ \\
\hline$\left(\right.$ Exrate $\left._{i j t}\right)$ & $\begin{array}{l}0.05 \\
(0.03)^{*}\end{array}$ & $\begin{array}{l}0.18 \\
(0.04)^{* *}\end{array}$ & $\begin{array}{l}-0.05 \\
(0.02)^{* *}\end{array}$ & $\begin{array}{l}0.12 \\
(0.01)^{* * *}\end{array}$ \\
\hline$\left(T O_{i t} \cdot T O_{j t}\right)$ & $\begin{array}{l}0.31 \\
(0.1)^{* *}\end{array}$ & $\begin{array}{l}1.65 \\
(0.15)^{* * *}\end{array}$ & $\begin{array}{l}0.2 \\
(0.1)^{* *}\end{array}$ & $\begin{array}{l}0.71 \\
(0.05)^{* * *}\end{array}$ \\
\hline$\left(\boldsymbol{F T} \boldsymbol{A}_{\boldsymbol{i j t}}\right)$ & $\begin{array}{l}0.54 \\
(0.18) * *\end{array}$ & $\begin{array}{l}0.16 \\
(0.18)\end{array}$ & $\begin{array}{l}-0.12 \\
(0.1)^{* *}\end{array}$ & $\begin{array}{l}0.2 \\
(0.1)^{* *}\end{array}$ \\
\hline$\left(\boldsymbol{W T O} \boldsymbol{O}_{i j t}\right)$ & $\begin{array}{l}0.8 \\
(0.2)^{* * *}\end{array}$ & $\begin{array}{l}2.73 \\
(0.5)^{* * *}\end{array}$ & $\begin{array}{l}0.6 \\
(0.3)^{* * *}\end{array}$ & $\begin{array}{l}0.7 \\
(0.1)^{* * *}\end{array}$ \\
\hline Fixed Effects & YES & YES & YES & YES \\
\hline Observations & 240 & 240 & 240 & 240 \\
\hline Log-likelihood & -12988.9 & -1131.03 & -2183.2 & -1043.4 \\
\hline R-squared & 0.77 & 0.7 & 0.86 & 0.90 \\
\hline
\end{tabular}

Source: Author's calculation based on gravity equation (3), estimated by STATA 14.

Note: ***0.01,**0.05, *0.1 level of significance.

According to $\left(R E F_{i j t}\right)$ results in all technological trade flow models. However, the Hecksher-Ohlin hypothesis is backed by research from existing model studies on technological trade flows, which are very different from that view and challenge countries with varying development levels with more trade than countries with the same level.

Pakistan's trade patterns are different from ASEAN countries' trade patterns, which increased the opportunity to enhance trade between Pakistan and ASEAN partners. The highest value calculated by the high-tech model, which is 1.7 percent, implies that high-tech trade flows increase as the difference between the per capita GDP of Pakistan and the ASEAN partner increases. The more significant similarity in relation to GDP means that the scale of the country's product variety in the differentiated product's market would increase Breuss \& Egger, (1999).

The diversity in consumers' tastes allows for an improvement in the yield of comparisons between Pakistan and the ASEAN partner in terms of technological trade flows. The study estimated positive and highly significant values for $\left(\operatorname{Simi}_{i j t}\right)$, which is highest in case of mid-tech trade flow between Pakistan and ASEAN partners and 
second highest in case of total bilateral trade flow. Coefficients of the exchange rate in all models are statistically significant. They have a positive sign in total bilateral trade, low tech trade, and high tech trade, whereas showing negative signs in medium-tech trade flows between Pakistan and ASEAN nations.

Economic growth in Pakistan depends heavily on its export market, but Pakistan's exchange rate, which allows costly imports to decrease exports, has long struggled to regulate. In the search for long-term interests and a trend for the liberalization of foreign markets, the exchange rate must be freely controlled according to market values. Trade openness coefficients appear highly significant in all technological trade flows, which is a highly appreciated sign for Pakistan and ASEAN nations to improve trade relations by signing trade and investment agreements and reducing tariffs in both sides to create business opportunities.

The trade agreement variable also demonstrates positive signs in all technological trade flows models. ASEAN-Pakistan FTA will benefit both parties, and it will enhance bilateral trade, which will improve the economic growth of Pakistan. The dummy variable WTO has a positive sign in all models, and the positive sign shows the participation of Pakistan and ASEAN countries into WTO will augment trade growth. One indistinct outcome for the WTO's member dummies is that Pakistan must take fiercely appropriate measures to enhance access to international-regional trade cooperation structures to facilitate trade activity in particular and economic cooperation in general.

\section{CONCLUSIONS AND RECOMMENDATIONS}

\section{Conclusions}

Pakistan wants to be a powerful presence in all ten members of the Association of Southeast Asian Nations. The CPEC network would generate a number of possibilities for trade and commercial connections with countries under it. ASEAN economic ties have grown in the last 20 years. It will display a strong concentration on low-tech and med-tech goods from Pakistan exports to ASEAN. Pakistan imports from the SouthEast Asian countries high concentration on med-tech and high-tech products, particularly processed foods, electronics, and machinery. It has highlighted the growth in strength of trade ties between Pakistan and ASEAN countries and the creation of their respective production and distribution networks.

According to the gravity model, a country's degree of economic growth substantially influences the cross-regional exchange flow. Technological trade flows models support the Hecksher-Ohlin theory. However, it stands in stark dissimilarity to this opinion and clutches that countries with dissimilar output levels will trade more than countries with similar levels. Due to the variety in consumers' taste, increased similarity yields increased technological trade volumes between Pakistan and ASEAN partners.

The study estimated positive and highly significant values for the similarity index. Downward exchange rate depreciation may exacerbate trade balance and further exacerbated by high import dependence in Pakistan. Policies of import substitution might be helpful to lower import dependence. Efforts can be made to maintain quality management of export products so that they will be able to restore credibility in foreign markets.

Pakistan and ASEAN also have excellent competitive advantages in exchange since they are both extremely trade-oriented countries. The benchmarks indicate that an ASEAN Pakistan trade agreement would be favorable to both countries. The PakistanASEAN trade agreement will maximize the quantum of intra-regional business opportunities. On the other side, the membership in WTO would carry along positive 
effects on the Pakistan-ASEAN bilateral trade. Pakistan mainly exports low-technology and medium-technology commodities to ASEAN nations which are food and textile goods, while its imports mainly include medium-technology and high-technology commodities, minerals, vehicles, and electrical equipment.

\section{Recommendations}

The study will provide valuable knowledge for fostering economic development and product specialization. Pakistan would sign an ASEAN-wide free trade agreement to facilitate bilateral trade with the country. Pakistan is losing capacity and productivity in the production line. The effect of this is to export the country's raw material requirements indirectly. Pakistan will need to diversify its export base to take advantage of the wide Asian demand. The study also suggests conducting more studies to identify the influence of microeconomic and macroeconomic factors on Pakistan's competitiveness in the ASEAN area. Pakistan should stabilize macroeconomic policies and ease of doing business to attract the market of ASEAN countries for trade cooperation in diverse areas. Future studies may concentrate on industry-relevant, e.g., quality improvement.

\section{REFERENCES}

Baharumshah, A. Z., Onwuka, K. O., \& Habibullah, M. S. (2007). Is a regional trading block a prelude to multilateral trade liberalization? Empirical evidence from the ASEAN-5 economies. Journal of Asian Economies, 18(2), 384-402.

Baier, S. L., \& Bergstrand, J. H. (2007). Do free trade agreements actually increase members' international trade?. Journal of International Economics, 71(1), 72-95.

Baltagi, B.H., Egger, P., \& Pfaffermayr, M. (2003). A Generalized Design for Bilateral Trade Flow Models. Economics Letters, 80(3), 391-7.

Batra, A. (2006). Asian economic integration, ASEAN+3+1 or ASEAN+1s?, Indian Council for Research on International Economic Relations, New Delhi, Working Paper No. 186.

Bergstrand, J.H. (1990). The Heckscher-Ohlin-Samuelson model, the Linder hypothesis and the determinants of bilateral intra-industry trade. The Economic Journal, 100(403), 1216-1229.

Breusch, T.S. \& Pagan, A.R. (1980). The Lagrange multiplier test and its applications to model specification in econometrics. Review of Econometric Studies, 47(1), 239-253.

Breuss, F., \& Egger, P. (1999). How reliable are estimations of East-West trade potentials based on cross-section gravity analyses? Empirica, 26(2), 81-94.

Clarete, R., Edmonds, C., \& Wallack, J.S. (2003). Asian regionalism and its effects on trade in the 1980s and 1990s. Journal of Asian Economics, 14(1), 91-129.

Eberhardt, M. \& Teal, F. (2011). Econometrics for Grumblers: A New Look at the Literature on Cross-Country Growth Empirics. Journal of Economic Surveys, 25(1), 109-155.

Egger, P.(2000). A Note on the Proper Econometric Specification of the Gravity Equation. Economics Letters, 66(1), 25-31.

Egger, P. (2002). An Econometric View on the Estimation of Gravity Models and the Calculation of Trade Potentials. World Economy, 25(2), 297-312.

Hallak, J. C. (2006). Product quality and the direction of trade. Journal of International Economics, 68(1), 238-265.

Head, K., \& Mayer, T. (2002). Illusory border effects: Distance mismeasurement inflates estimates of home bias in trade (Vol. 1). Paris: CEPII. 
Helpman, E., Melitz, M., \& Rubinstein, Y. (2008). Estimating trade flows: Trading partners and trading volumes. The quarterly journal of economics, 123(2), 441487.

Hoang, N. T. T., Truong, H. Q., \& Van Dong, C. (2020). Determinants of Trade Between Taiwan and ASEAN Countries: A PPML Estimator Approach. SAGE Open, 10(2), 2158244020919516.

Iqbal, J., \& Nosheen, M. (2020). Economic \& Cultural Distance \& Regional Integration: Evidence from Gravity Model Using Disaggregated Data for Pakistan. The Pakistan Development Review, 59(2), 243-274.

Irshad, M. S., Xin, Q., Shahriar, S., \& Arshad, H. (2017). A panel data analysis of China's trade pattern with OPEC members: Gravity model approach. Asian economic and financial review, 8(1), 103-116.

Irshad, M. S., Xin, Q., Xuan, P., \& Arshad, H. (2016). Deltoid analysis of PakistanASEAN-China free trade agreements and opportunities for Pakistan. Asian Economic and Financial Review, 6(5), 228-237.

Irshad, M.S. \& Xin, Q. (2015). Rising trend in import and exports of Pakistan FTA partners in recent years. Academic Research International, 6(4), 320-331.

Irshad, M.S. \& Xin, Q. (2017). The gravity behind South Korea's international trade: A panel data approach. The Myanmar Journal, 4(2), 76-89.

Irshad, M.S., \& Anwar, S. (2019). The Determinants of Pakistan's Bilateral Trade and Trade Potential with World: A Gravity Model Approach. European Online Journal of Natural and Social Sciences, 8(4 (s)), 1-19.

Irshad, M.S., Xin, Q. \& Arshad, H. (2015). One Belt One Road: Does China-Pakistan Economic Corridor benefit for Pakistan's Economy?, Journal of Economics and Sustainable Development, 6(24), 200-207.

Irshad, M.S., Xin, Q., Hui, Z., \& Arshad, H. (2018). An empirical analysis of Pakistan's bilateral trade and trade potential with China: A gravity model approach. Cogent Economics \& Finance, 6(1), 1-18.

Irshad, M.S., Xin,Q., Shahriar,S., \& Ali, F., (2018). South Korea's potential export flow: a panel gravity approach. Asian Journal of Empirical Research, 8(4), 124139.

J. S. Silva \& S. Tenreyro. (2011). Further simulation evidence on the performance of the Poisson pseudomaximum likelihood estimator. Economics Letters, 112(2), 220-222.

Kabir, M., \& Salim, R. (2010). Can Gravity Model Explain BIMSTEC's Trade?. Journal of Economic Integration, 25(1), 143-165.

Kien, N. T. (2009). Gravity model by panel data approach: an empirical application with implications for the ASEAN free trade area. ASEAN Economic Bulletin, 26(3), 266-277.

Kreinin, M.E., \& Plummer, M.G. (1992). Effects of economic integration in industrial countries on ASEAN and the Asian NIEs. World Development, 20(9), 1345-1366.

Lee, J. W., \& Swagel, P. (1997). Trade barriers and trade flows across countries and industries. Review of Economics and Statistics, 79(3), 372-382.

Magee, C. (2003). Endogenous preferential trade agreements: An empirical analysis. Contributions to economic analysis and policy, 2(1), 1-17.

Moscone, F. \& Tosetti, E. (2009). A Review and Comparison of Tests of Cross-Section Independence in Panels. Journal of Economic Surveys, 23(3), 528-561.

Musleh, D., G. Ejaz \& Q. Usman. (2009). Recent experience and future prospects of Pakistan's trade with China. Lahore Journal of Economics, 14(SE), 87-110.

Naya, S. F., \& Plummer, M.G. (2006). A quantitative survey of the economics of ASEAN-US free trade agreements. ASEAN Economic Bulletin, 23(2), 230-252. 
Pesaran, M.H. (2004). General diagnostic tests for cross section dependence in panels. IZA Discussion Paper No. 1240. available at: http://repec.iza.org/dp1240.pdf

Plummer, M.G. (1997). ASEAN and the theory of regional integration: A survey. ASEAN Economic Bulletin, 14(2), 202-214.

Pöyhönen, P. (1963). A tentative model for the volume of trade between countries. Weltwirtschaftliches Archiv, 93-100.

Rasoulinezhad, E. (2016). Investigation of Sanctions and Oil Price Effects on the IranRussia Trade by Using the Gravity Model. Vestnik of St Petersburg University, Series 5 (Economics), 2, 68-84.

S. Yang \& I. Martinez-Zarzoso, (2014). A panel data analysis of trade creation and trade diversion effects: The case of ASEAN-China Free Trade Area. China Economic Review, 29, 138-151.

Serlenga, L., \& Shin, Y. (2007). Gravity Models of Intra-EU Trade: Application of the CCEP-HT Estimation in Heterogeneous Panels with Unobserved Common TimeSpecific Factors. Journal of Applied Econometrics, 22(2), 361-81.

Silva, J. S., \& Tenreyro, S. (2006). The log of gravity. The Review of Economics and Statistics, 88(4), 641-658.

Silva, J.S., \& Tenreyro, S. (2011). Further simulation evidence on the performance of the Poisson pseudo maximum likelihood estimator. Economics Letters, 112, 220222.

Thorbecke, W. (2015). China-US trade: a global outlier. Journal of Asian Economics, 40, 47-58.

Tinbergen, J. (1962). Shaping the World Economy: Suggestions for an International Economic Policy. New York: The Twentieth Century Fund.

Trefler, D. (1993). Trade liberalization and the theory of endogenous protection: an econometric study of US import policy. Journal of Political Economy, 101(1), 138-160.

\section{APPENDIX}

Table 5. Pakistan's technological bilateral trade with ASEAN nations in 2018. (US\$ 1000)

\begin{tabular}{lrrrrrr}
\hline \multirow{2}{*}{ Country } & \multicolumn{3}{c}{ Imports } & \multicolumn{3}{c}{ Exports } \\
\cline { 2 - 7 } & Low-tech & Med-tech & High-tech & Low-tech & Med-tech & High-tech \\
\hline Brunei & - & 8 & - & 210 & 6 & - \\
Cameroon & 0.021 & 20 & 1 & 2438 & 6959 & - \\
Indonesia & 60155 & 353743 & 20123 & 36753 & 4888 & 113 \\
Lao PDR & 0.2 & 1889 & 4 & 232 & 43 & - \\
Myanmar & 14 & 1 & 1 & 5603 & 119 & 71 \\
Malaysia & 70285 & 148510 & 47046 & 39327 & 9189 & 21 \\
Philippines & 1315 & 26195 & 5247 & 18142 & 26973 & 383 \\
Singapore & 23562 & 382332 & 60480 & 22843 & 5015 & 618 \\
Thailand & 104496 & 1001612 & 41656 & 17907 & 11305 & 213 \\
Vietnam & 61472 & 30651 & 126326 & 77528 & 4752 & 33 \\
\hline ASEAN & 321300 & 1944961 & 300882 & 220983 & 69252 & 1451 \\
\hline SOurce:
\end{tabular}

Source: Author's compilation based on WITS database

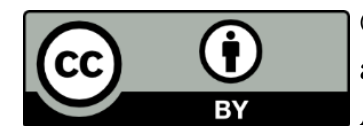

(C) 2021 by the authors. Licensee JPPD, Indonesia. This article is an open-access article distributed under the terms and conditions of the Creative Commons Attribution (CC BY) license (http://creativecommons.org/licenses/by/4.0/). 